\title{
MONGOL-ARMENIAN MILITARY COOPERATION: STAGE I: THE CONQUEST OF THE MIDDLE EAST (1258-1260)
}

As has been said earlier, during his journey to Mongolia in 1253/1254, the Armenian King Het'um agreed to ally with the Mongol Empire and submitted the Mongol Great Khan. The implementation of this agreement occurred only when the Chinggisid lineage imposed its own supremacy, later known as the Il-Khanate, over the Caucasus, Asia Minor, Iran and Upper Mesopotamia after 1256.

The main allies of this campaign were King Het'um from Cilicia, the Greater Armenian lords under the Georgian King David Ulu and the Mongol Prince Hülegü, ${ }^{1}$ who promoted himself as a founder of the Mongol dynasty in this region. Hülegü aimed to restrain the two independent powers of the eastern Islamic world: The principality of the Ismāî̀i imams in Māzandarān (Țabaristān)2 and the 'Abbasid Caliphate of Baghdad. This move against these Islamic powers perfectly suited the Armenians' wishes. The timing was appropriate; although there were several local politically-influential dynasties in Persia and Syria, there was no centralised power in that region at

${ }^{1}$ Hülegü was the fifth son of Tolui Khan by his chief wife Sorqoqtani Beki. Tolui Khan, known as Ulugh-Noyan in Muslim sources, was otchigin (the youngest) of the chief sons of Chinggis Khan. He was a great winner of battles, for no princes conquered as many lands as he did, some alongside his father, including Bukhara, Samarqand, Badakhshan, Khurasan, Merv, Maruchuq, Sarakhs, Nishapur, Quhistan and Herat (Rashīd al-Dīn, 1971:163-165). He died from illness in the campaign against the Jürchen-Chin in 1232 (MNT, 2004:95-96[\$272]). Sorqaqtani Beki gave her orphaned children an education not only in good manners, but also in army training (Rashīd al-Dīn, 1971:168-169). Two of her sons, Möngke (r. 1251-1259) and Qubilai (r. 1260-1294) became the Great Khans and her son Hülegü (r. 12561265) became the first Il-Khan. The senior wife of Hülegü was Doquz (Toghuz) Khatun, who had previously been a wife of Tolui. She was a powerful woman who was held in great respect. Since she was from the Nestorian Kereit tribe, she constantly supported the Christians. For Doquz Khatun, see Spuler, 1972:121-122; Melville, 1996c:475-476. Hülegü allowed her to build churches and to carry a movable church-tent within her camp (Rashīd al-Dīn, 1954:678). She saved many Christians from death during the sack of Baghdad.

2 The Ismāîlīis maintained a strong state of their own from $483 \mathrm{H}$. (1090) to 654 H. (1256) (Hodgson in Boyle, 1968:422). 
that time. ${ }^{3}$ Therefore, these two Islamic regimes became the target for the Mongols after they had extended their power into the territories of the Seljuk Sultanate of Rūm, as the result of their victory at Köse Dagh. However, Hülegü decided to advance further and conquer Syria and Egypt. The achievement of Hülegü as a conqueror follows along with the narrative in what way Mongol-Armenian cooperation was carried on.

Hülegü (r. 1256-1265) and the Greater Armenian Forces against the Muslim Supremacies

At the end of 1256, Prince Hülegü of the Chinggisid lineage came to govern Iran, Rūm and the Caucasus. The initial assistance that Hülegü received from the Armenian lords occurred during his confrontation with the Ismāi îlīs. ${ }^{4}$ In 1256, David VII Ulu, the King of Georgia (r. 1247-1270) with Armenian and Georgian auxiliaries took part in the Mongol conquest of Alamut. ${ }^{5}$

\section{Armenian Provision of Aid to the Mongols}

In 1251, Baiju Noyan, who was a supreme Mongol figure in Iran, the Caucasus and Anatolia, made complaints about the Ismāîlīs and about the Caliph of Baghdad to Güyük's first cousin and successor Möngke Khan. ${ }^{6}$ This information given by Rashīd al-Dīn is supported by Kirakos Gandzakets'i, who, in his Patmut'iwn Hayots (History of the Armenians), states that the Ismā'îlīs killed Chaghatai Noyan, one of the Mongol generals in Armenia and a friend of Awag Zak'arian in the 1240s. ${ }^{7}$

\footnotetext{
${ }^{3}$ Morgan, 1990:145.

${ }^{4}$ The Ismāî̀ilis were a branch of the Shīî̀ sect of Islam, a radical sect and one of the main divisions of the Muslim faith from the tenth century. At the end of the eleventh century and the beginning of the twelfth, the members of this sect in Syria and Iran had been driven from the cities and had taken refuge in the mountains of northern Syria and northern Iran. In Iran, they had established a series of castles on rugged peaks in remote areas. Their defence was secured by fortifying themselves in remote mountains and by the use of suicide assassins to dispose of enemy leaders (Kennedy, 2002:164).

${ }^{5}$ Mkhit'ar Ayrivanets'i, 1860:67.

${ }^{6}$ Rashìd al-Din, 1954:684. Based on the complaints of Shiramun, the son of Chormaghan, Güyük had previously expressed his disappointment to the Caliph Ambassador (Rashīd al-Dīn, 1954:570).

${ }^{7}$ Kirakos Gandzakets'i, 1961:264, 275. For Chaghatai Noyan and Awag Zakarian, see Chapters 2 and 3.
} 
Information about the Ismāîlīs reveals that there was both a diplomatic and military relationship between the Mongol khans and the Ismā îli leaders from the early decades of the thirteenth century; emissaries of Imām Jalāl al-Dīn Hasan (1210-1221) visited Chinggiz Khan to express their goodwill as early as $1219 . .^{8}$ This probably explains why, during the first Mongol invasions of Khurasan in 1220-1221, the Mongol force did not raid the region of Kūhistān and many refugees, including Nașīr al-Dīn al-Ṭūsī (1201-74) found shelter there. ${ }^{9}$ In 1246, 'Alā al-Dīn Muhammad (r. 1221-1255) dispatched another mission, led by two senior Ismā îli $d \bar{a}$ ' $\bar{s}$ (missionaries), to Güyük Khan for the occasion of his enthronement ceremony. ${ }^{10}$ But, by that time, something had changed in the Mongol attitude towards the Ismāiliss, the real cause of which is not clear. It is only known that, as Rashīd al-Dīn attests, Güyük gave a very angry reply to the letter brought by the ambassadors of Alamut, and he dispatched reinforcements to the Mongol armies already stationed there, with instructions to reduce Muslim forts, beginning with the Ismāîlīs. ${ }^{11}$ Güyük intended to follow afterwards but his death prevented him.

The relationship of the Ismā îlīs with the Mongols deteriorated as a result of complaints about the military and political activities of the Ismāîlis in the region. These complaints were received at the Mongol court not only from Mongol commanders, but also from 'ulama', the Sunni scholars. ${ }^{12}$ In addition, there was a direct threat from the Ismā'îlis in Mongolia. In his travel record, Friar Rubruck mentions 400 assassins who arrived at the court of Möngke Khan under various disguises with the purpose of killing the Khan. ${ }^{13}$

\footnotetext{
${ }^{8}$ Juvayni, 1962:248; Jamal, 2002:45. From the very moment of his accession, the Ismāīîi Imām Jalāl al-Dīn Hasan professed Islam and strictly forbade his people from adhering to the heresy urging them to follow the rites of the Shari'a. He became known as Jalāl al-Dīn the Neo-Muslim (Juvaynī, 1962:243).

${ }^{9}$ May, 2004:233. On Nașir al-Dīn al-Ṭusīi and the Ismāîlīs, see Dabashi, 1996:231-245.

${ }^{10}$ Juvaynī, 1962:205; Daftary, 1998:150.

${ }^{11}$ Rashīd al-Dīn, 1954:50, 570

12 Jamal, 2002:46.

13 Dawson, 1955:184; Morgan, 1990:148; Rubruck, 1990:222. The number 400 seems to be a symbolic number. Besides this, as Jūzjānī recounts, all the people of the city of Qazvīn made great preparations for warfare with the Ismāi ilis of Alamut, due to daily conflicts that were taking place between the Qazvīnīs and the Ismāîlīis. Qãzị Shams al-Dīn Qazvīnī, the sincere Imām, according to Jūzjānī, who attended Güyük
} 
One can find the same notion in the Zafar-Näma (ca. 1335) of Mustawfì Qazvīnī, where the Qāẓi from Qazvin warns of the danger from the Ismāi ìlis at Möngke Khan's court. Moreover, according to Mustawfī Qazvīnī, the choice of Hülegü to be sent to Iran was approved by the Qāzị. ${ }^{14}$ It is uncertain whether the Qāẓ̂ had such an influence on the Mongol court. This is surely a later interpretation; however, the source speaks for the close relationship between the two parties.

Indeed, Möngke Khan recognised that the Ismāi îlis might pose a serious threat to the trade routes and communication. He also realised that there were lands nearby in Iran conquered during the time of Chinggis Khan and not yet belonging to him. Therefore, according to Rashīd al-Dīn, he decided to allot these lands to his brother Hülegü, who was expected completely to subjugate Iran, Syria, Rūm and Armenia. ${ }^{15}$ Hülegü was also dispatched to put an end to the provisional regime of Mongol military rule and fiscal administration in the region. ${ }^{16}$

According to Juvaynī, Hülegü set out 'from Qara-Qorum against the Heretics into the land of the Tajjiks in the year of the Ox (1253). ${ }^{{ }^{17}}$ Hülegü did not reach Iran before the beginning of $1256^{18}$ but he had dispatched in advance an army of 12,000 men from Mongolia in 1252 under the command of Ket-Buqa of the Naiman tribe, the Nestorian Christian, to join the Mongol garrisons already camping in Iran. ${ }^{19}$ Ket-Buqa crossed the Oxus in 1253 and the initial confrontation between the Mongols and the Ismā îlis occurred in Kühistān when

Khan's coronation ceremony, travelled several times to Mongolia, until the time of Möngke Khan, to obtain aid in his fight with the Ismāîlīs (Jūzjānī, 1970:1189).

${ }_{14}^{14}$ Qazvīnī, 1999:1118-1120; Lane, 2003:16.

${ }^{15}$ Hülegü was instructed to apply the law of Chinggis Khan in the territories between the Amu Darya and Egypt (Rashīd al-Dīn, 1954:685).

${ }^{16}$ Ibid., 686.

${ }^{17}$ He was accompanied by two of Jochi's grandsons, Balaghai and Quli, and one of his great-grandsons, Tutar (and by one of Chaghatai's grandsons, Tegüder) (Rashīd al-Dīn, 1954:707; Juvaynī/Boyle, 1962:91). Möngke Khan also sent another brother, Qubilai, to consolidate Mongol conquests in China including Khitai, Machin, Karajang, Tangqut, Tibet, Jurje, Solanga, Gaoli and a part of Hindustan. Qubilai later became a founder of the Yüan dynasty in China and succeeded Möngke as Great Khan (Rashīd al-Dīn, 1954:685; Boyle, 1968:340).

${ }_{18}$ Exercising his seniority among the Chinggisids, Batu Khan forbade Hülegü from crossing the Oxus River (Amu Darya); only after the death of Batu in 1255, did Hülegü move towards Iran (Trepavlov, 1993:81).

19 Ket-Buqa Noyan had the rank of ba'urchi (Rashīd al-Dīn, 1954:686; Juvaynī, 1962:95). The ba'urchi, I believe, was a Mongol officer in charge of food safety for the Great Khans, rather than a simple cook/steward. 
Ket-Buqa attacked several Ismāî̀ī strongholds, putting their inhabitants to the sword before laying siege to Girdkūh castle. ${ }^{20}$

In 1256, Hülegü came to Iran through the Chaghatai Ulus, ${ }^{21}$ crossing the Amu Darya and passing the eastern borders of Transoxiana, Herat and Kūhistān. ${ }^{22}$ On his arrival at the Persian bank of the Amu Darya, news about him coming to destroy the Ismāîlīs was spread to the Lords of Rūm, Fars, Iraq, Azerbaijan, Arran, Shirvan and Georgia. All of them came to him with many gifts to acknowledge their services. ${ }^{23}$ Since Georgia was named, it is understood that the Armenian princes did the same.

According to the Armenian sources that confirm the picture given by the Persian historian it is understood that the actions against the Ismāîlīs were unavoidable. The reference given in the Chronicle of Smbat Sparapet, states that in the year 702 (1253), when King Het'um I went east to Möngke Khan, he had to dress as a cattle driver in order to pass through the lands of the Ismā îlis in Cappadocia. ${ }^{24}$ Kirakos Gandzakets'i gives an interesting account of the Ismāi îlis or Mulheds: $:^{25}$

There was a nobleman, called Orghan ... who was killed in Gandzak by the Mulheds [heretics], who were accustomed to kill people secretively. Some people approached him [Orghan] while he was walking on the street, as if someone had threatened them and they approached him for justice. Having a piece of paper in their hands they showed it to him, shouting and begging: 'Justice, justice!' When he [Orghan] stopped and wanted to inquire about who had assaulted them, they jumped upon him from here and there, and with the sword which they had concealed, stabbed and killed him ... They killed many people and fled through the city, because this nation was accustomed to behaving in such a way. They encroached upon the fortified places called T'un and $\mathrm{T}^{\prime}$ anjak as well as the forests of Lebanon, taking their blood-price from their prince, whom they worshipped instead of God ... They went many times wherever their prince sent them being frequently in various

${ }^{20}$ Boyle, 1968:341. Girdkūh only surrendered after about 20 years in 1271 in Abaqa Khan's time (Rashīd al-Dīn, 1954:766).

${ }^{21}$ The territories north of the Pamir and T'en Shan mountains, held by Chaghatai, the second son of Chinggis Khan (Manz, 1999:4).

${ }^{22}$ Juvaynī/Boyle, 1997:612-618. According to Baiḍāwī, Hülegü spent the winter in Khurasan, and then he set off for Kūhistan (Melville, 2007:52-58).

${ }^{23}$ Rashīd al-Dīn, 1954:688.

${ }^{24}$ Smbat Sparapet in Galstyan, 1962:49.

${ }_{25}$ Being regarded as a heretical sect of Islam, the Ismāîliss were referred to as Mlheds $\left(V_{L} h h_{i} \eta\right)$ [mulhids] by Vardan Arevelts'i, 1991:149, and Hashishik' (Zuchichf) by Het'um Patmich', 1956:70. 
disguises until they found the appropriate moment to strike and then to kill whomever they wanted. Therefore all the princes and kings feared them and paid tax to them. And they [the Ismāi ìis] strictly followed the orders of their prince and did whatever he said, even to commit suicide. Thus, they killed many dignitaries who did not pay them tax, as well as killing this impious man [Orghan]. ${ }^{26}$

This extract may explain why the Armenians were later involved in the Mongol fight against the Ismầiliss, as they were the main providers of foodstuffs for the Mongol armies. ${ }^{27}$ When messengers were sent to all subjugated lands to procure food for the Mongol army and its horses, it was decided to transport provisions from Armenia to Yazd. Everyone in these territories without exception was forced to pay the food levies of ulagh and taghar, ${ }^{28}$ even in Greater Armenia when the whole country faced a severe famine in $1256 .{ }^{29}$ It seems that in addition to the political reasoning, there was an economic reason why the Armenians were interested in the elimination of Ismāî̀ì power.

The Mongol model of siege tactics and negotiations led to the defeat of the Ismâîliss. ${ }^{30}$ It was on 19 November 1256 when the last of the Ismā'îli imams, Rukn al-Dīn, submitted ${ }^{31}$ and Hülegü's victory was recognised as a great service to orthodox Islam. ${ }^{32}$ It is noted by Bar Hebraeus as follows:

And by means of these blessed captures God had mercy on all the kings of the Arabs and Christians who lived in terror and trembling through the fear of the Ishmaelites who were carriers of daggers and were shedders of innocent blood. ${ }^{33}$

After his victory over the Ismāîlīs, Hülegü decided to live in the Mughan plain that had previously been occupied by Baiju Noyan;

${ }^{26}$ Kirakos Gandzakets'i, 1961:226-228.

27 Rashīd al-Dīn, 1954:695.

${ }^{28}$ Juvaynï/Boyle, 1962:112. For the ulagh and taghar, see Chapter 4.

${ }^{29}$ Sebastats'i in Hakobyan, 1956:142.

${ }^{30}$ On the pattern of Mongol tactics, see Chapter 2.

${ }^{31}$ Juvaynī/Boyle, 1962:133. The Syrian Ismāìlīs escaped Mongol rage; some Ismā îlīs remained in Iran and fled to India in the nineteenth century, establishing there the seat of the Nizārī Ismāi îli imamate. Their ultimate successor, the Aga Khan, is still the head of the sect (Daftary, 1998:4; Morgan, 1990:151).

${ }^{32}$ Boyle, 1968:345. In the eleventh century, Sunnì scholars began to establish orthodox colleges, madrasas, to rival the Ismā îlì mission schools organised in Cairo and elsewhere. The madrasa system was extended to Baghdad and later to Egypt (Lewis in Hussey, 1966:658-659).

${ }^{33}$ Bar Hebraeus, 2003:423. 
therefore, Hülegü ordered Baiju to move to the inner lands of Rūm (in Bithynia), vacating Caucasian Albania, Georgia and Armenia for himself. ${ }^{34}$ According to Vardan Arevelts'i, the Armenians and the Georgian King David welcomed Hülegü. ${ }^{35}$ The replacement of Baiju by Hülegü and thus the shift of Baiju's base from Mughan was a strategic change in the nature of Mongol rule in the region. It was the beginning of the formation of a new Mongol state to be known as the Il-Khanate. Being of direct Chinggisid lineage, Hülegü took control and supremacy over the Mongol noyans stationed in Rūm, Iran, Afghanistan and the Caucasus. According to Grigor Aknerts'i, after the victory over the 'Abbāsid Caliph, Hülegü dispatched his envoys to the Great Khan Mönkge to ask for his next orders. Mönkge Khan sent back his judges to install Hülegü as a Khan of that land. When the messengers reached Hülegü, they convened a quriltai, or assembly, to which all the noyans stationed in the region were invited. Some of them submitted to the command of Hülegü, while some refused. ${ }^{36}$ Hülegü's next move was directed against the 'Abbasid Caliphate of Baghdad, a domain of Sunnite Islam in 'Irāq-i 'Arab, to the accomplishment of which the Armenian lords contributed greatly.

\section{An Armenian Envoy Sent to the Caliph}

Rubruck states in his account that he saw the ambassador of the Caliph of Baghdad at the court of Möngke-Khan. However, according to Rubruck's narration, two contradictory accounts are given to explain the Caliph's ambassador's presence in Qara-Qorum. First, Rubruck was told that the Caliph of Baghdad had made peace with the Mongols, and the ambassador was to give 10,000 horses to the Mongol Army. ${ }^{37}$ Second, Mönkge Khan refused to make peace unless the 'Abbasid Caliph destroyed his fortresses, to which the ambassador replied: 'When you remove all your horses' hooves, we shall

${ }^{34}$ Kirakos Gandzakets'i, 1961:374; Bar Hebraeus, 2003:424-425. Baiju was ordered to move west into the territories of the Seljuk Sultanate of Rūm which were disputed between the two sons of Kay-Khusraw II. Since 'Izz al-Dīn Kaykā'ūs (Kay Kāwūs) was defeated by the Mongols at Aqsaray in 1256, his younger brother, Rukn al-Dīn Qilich (Kilıc) Arslan was recognized as ruler (Cahen, 2001:184-186).

${ }^{35}$ Vardan Arevelts'i, 1991:149.

${ }^{36}$ Grigor Aknerts'i, 1974:44. No similar reference is found in Persian sources, allowing the Armenian source to consider a justification of Hülegü's rulership.

37 Rubruck in Komroff, 1989:187; Rubruck, 1990:247. 
destroy all our fortifications. ${ }^{38}$ Based on these two statements, one can assume firstly that Rubruck had visited Mongolia during 12531255 and, secondly, that there were contacts between Mongolia and the Caliphate of Baghdad while peace prevailed. Nevertheless, the character of this relationship changed towards hostility due to the expansion of Mongol power from Iran into Iraq. If we believe the Secret History of the Mongols, the conquest of Baghdad was set up as early as 1221 during the time of Chinggis Khan when he was stationed in Tālighān, and Chormaghan and other commanders suggested bringing down the "Abbasid Caliphate. ${ }^{39}$ This idea was carried through the reigns of the succeeding three Great Khans and was implemented only in the time of Hülegü.

Nonetheless, there is an alternative scholarly view on this matter, where the Mongol move against Baghdad connected with the ambition of Hülegü, who wished to consolidate the Middle East under Mongol control. Hülegü's anger may have turned the Mongols against the 'Abbasid Caliphate, when the latter refused to send troops to assist the Mongol fight against Ismā îli power. ${ }^{40}$ This opinion seems not to be well founded for two reasons. Firstly, it disregards the Mongols' plan of 1221 and, secondly, it devolves responsibility for the whole conquest of Baghdad solely to one person's anger or ambition. It is worth remembering that, in the mid-1250s, the central court of the Mongol Empire was still in charge of peripheral business and that the ideas conceived by Chinggis Khan were carried forward.

Detailed information on the stages of the Mongol advance to Baghdad is found in a Persian chronicle, which states that from September 1257 onwards, Hülegü and Caliph Musta'șim (r. 12421258) exchanged several messages in which the Caliph refused to accept the Mongols' warning and to hand over his domain. ${ }^{41}$ Hülegü established contact with the Caliph's governor of Dartang and the commander Ket-Buqa persuaded him to hand over the castles in his area. By this action, Ket-Buqa secured his passage through the Zagros Mountains. ${ }^{42}$

\footnotetext{
38 Ibid., 247.

39 MNT, 2004:91(\$260); SHM, 2001:252.

40 Amitai-Preiss, 2004:16.

41 Rashīd al-Dīn, 1954:699-705.

42 Ibid., 705-707.
} 
In November 1257, Hülegü set off from Hamadān in the direction of Baghdad. He was accompanied by two of Jochi's grandsons, Balaghai and Quli, one great-grandson, Tutar, and by one of Chaghatai's grandsons, Tegüder. ${ }^{43}$ Since Baghdad shared a common border with Mosul and knowing that Badr al-Dinn Lu'lu', the atabeg of Mosul, who had already supported the Mongols, would assist him, Baiju came from Anatolia to the west bank of the Tigris by the Mosul road. ${ }^{44}$ With him were the forces of the Armenian Prince Zak'arē, the son of Shahnshah Zak'arian and Prince Prosh Khaghbakian. ${ }^{45}$ The Mongols placed considerable trust in these Armenian lords, whose assistance they had received since the 1230s. The right flank of Hülegü, commanded by Generals Balaghai, Tutar and Quli advanced through Shahrazūr and Daqūqā. Kit-Buqa commanded the left wing coming by way of Luristān and Khūzistan. The centre under Hülegü came down via Kirmānshāhān and Hulwān. ${ }^{46}$ The Mongol armies converged on Baghdad in January 1258. Caliph Musta șim still hoped that he could successfully trick the Mongols as his predecessors had done for more than 500 years with the Būyids, Seljuks, Khwārazmians and others who had infringed upon their dominions. ${ }^{47}$

As usual, Hülegü sent an emissary to the Caliph asking for obedience. According to Kirakos Gandzakets'i, the Armenian Prince Prosh Khaghbakian was entrusted with the very important role of leading this emissary. ${ }^{48}$ It is not known on what grounds he was selected to be the ambassador. Unfortunately, the delegation received a reply full of insults, on receipt of which the Mongols surrounded the Caliph's army. The davāt-dār (chief secretary) who commanded the Caliph's army was encamped between Ba'qūbā and Bājisrā. Hearing that the Mongol army was approaching from the west, the davāt-dār crossed the Tigris and joined battle with the Mongols near Anbār. ${ }^{49}$ The Mongols retreated and, joining Baiju's main army,

${ }^{43}$ Ibid., 707. The death of the first three princes would cause Hülegü a very high price: War with the Golden Horde.

${ }^{44}$ Badr al-Dīn Lu'lu' was obliged to supply provisions, weapons and a bridge of boats over which Baiju's army crossed the Tigris (Patton, 1991:60).

${ }^{45}$ Kirakos Gandzakets'i, 1961:380.

${ }^{46}$ Rashīd al-Dīn, 1954:707.

${ }^{47}$ Ibid., 700.

${ }^{48}$ Kirakos Gandzakets'i, 1961:380. Pŕosh Khaghbakian was a lord of the Khaghbakian or Pŕoshian House in Urkghunk', Boloraberd, Eghegiats' Dzor and Hrashk'aberd from 1223 to 1284 (Babayan, 1976:549).

${ }^{49}$ Kirakos Gandzakets'i mentions that the Dawdar (davāt-dār) at first was victorious, killing some 3,000 Mongols and sending messengers to the Caliph following 
opened a canal on the river Tigris. Half of the Caliph's army was drowned and half was defeated in the attacks that followed. ${ }^{50}$ The davāt-dār made an attempt to escape by boat down the Tigris. Being unsuccessful, he fled back to Baghdad. When the Caliph heard about this, he sent his Shi' ite vizier to soothe Hülegü. However, it was useless. The Mongols had already attacked the whole of the eastern fortifications of Baghdad. On 10 February, the Caliph came to Hülegü in person along with all three of his sons to surrender. ${ }^{51}$ The sack of Baghdad lasted seven days (from February 13 to 20), and during which the population of several thousands was massacred. ${ }^{52}$ With the help of Doquz Khatun, Hülegü's Nestorian wife, many Christians were spared during the devastation of Baghdad in $1258 .{ }^{53}$ The destruction of the Sunnī Caliphate in Baghdad was a great advantage for Shì 'issm, and the sparing of Shī'as in 1258 was due to the presence of a Shīîi theologian, Nașīr al-Dīn Țūsī. ${ }^{54}$

\section{The Armenian Account of the Fall of Baghdad}

The History of Kirakos Gandzakets'i gives a detailed account of the fall of Baghdad..$^{55}$ Gandzaketsi's source was Prince Prosh Khaghbakian, a participant and eyewitness of the conquest. ${ }^{56}$ The Armenian historian traces several points in the Mongol victory over the 'Abbasid Caliphate. First, he says that Hülegü ventured against the Caliph with an army of multinational subjects. ${ }^{57}$ Secondly, he states that the

his triumph (Kirakos Gandzakets'i, 1961:379).

${ }^{50}$ Because the Caliph's troops were encamped on low-lying ground, the Mongols made a breach in the banks of the river so that water poured down on the enemy at midnight (Bar Hebraeus, 2003:430).

${ }^{51}$ Rashīd al-Dīn, 1954:712.

52 Ibid., 712-713. The number involved in the massacre varies in Muslim sources. Some give 800,000 (Morgan, 1990:151). In Hűlegü's letter to King Louis IX of France, the Il-Khan gives the number of casualties in Baghdad as 200,000 (Meyvaert, 1980:256). All these numbers are highly unreliable.

${ }^{53}$ Vardan Arevelts'i, 1991:150; Kirakos Gandzakets'i, 1961:382. For Doquz Khatun, see Melville, 1996c:475-476; cf. Jackson, 2003:200-201.

${ }^{54}$ Boyle, 1968:538-539.

55 Kirakos Gandzakets'i, 1961:377-384.

${ }_{56}$ Pŕosh (Hasan) Khaghbakian himself told Kirakos Gandzakets'i about events surrounding the capture of Baghdad (Kirakos Gandzakets' $i$, 1961:384).

57 Ibid., 378. A military levy of two out of ten men was imposed by the Mongols in Armenia and Georgia, so obviously contingents of Hülegü's force were composed of multinational recruits as Kirakos Gandzakets'i states. For the military levy, see Chapter 4 (Martinez, 1986/1988:129-242). Juvaynī states that even earlier, the Turks 
Mongol Prince planned his raid on Baghdad very carefully, examining the location of the city. Certainly, Hülegü saw that there was only one route that would give the Caliph of Baghdad a chance to flee: The great river Tigris. Therefore, he sent Baiju who was stationed in Rùm to guard all possible exits to the river. In executing Hülegü's order, Baiju constructed a floating bridge across the river and sank sturdy nets with iron hooks and pipes into the water so that no one could swim through to freedom. ${ }^{58}$ Next, Kirakos Gandzakets'i describes how Hülegü reacted to the boastful words of the Caliph, who called him a 'Turkic dog,' by ordering the demolition of the city walls. Then, when the walls were demolished, he gave an order to rebuild them. ${ }^{59}$ This act perhaps does not correspond to reality, but it signifies the destiny of Baghdad, together with Hülegü's superiority. Another aspect of Kirakos Gandzakets'i's narration deals with the deaths of the two sons of Caliph Musta șim: Hülegü's son slew one, while the other one was given as a sacrifice to the river Tigris. ${ }^{60}$ The most fascinating point of this source is that the Armenian historian records how Hülegü killed the Caliph himself with his own hands, so giving us another version of the Caliph's death. ${ }^{61}$ Kirakos' narration is not supported by other sources, although he gives as his own source Pŕosh Khaghbakian, an actual participant in this event. As Boyle asserts, the last day of the 'Abbāsid Caliph is reported differently in different sources, whether Muslim or Christian. ${ }^{62}$ Based on the account attributed to Nașīr al-Dịn Țūsī, the story that is repeated by Marco Polo, Joinville, Het'um and others relates how the Caliph Musta șim was shut in the tower with his treasure and starved to death. ${ }^{63}$ According to Grigor Aknerts'i, the Caliph was trampled under the feet of the Mongol troops and this was how Hülegü slew him. ${ }^{64}$ Rashīd al-Dīn states that on 20 February 1258, in the village

and Tajiks were ready to join Hülegü's troops in attacks on the Ismāîlī castles (Juvaynī/Boyle, 1962:102).

${ }^{58}$ Kirakos Gandzakets'i, 1961:379.

59 Ibid., 380.

${ }^{60}$ Kirakos Gandzakets'i, 1961:382. According to Rashīd al-Dīn, the youngest son of the Caliph was given to Öljei-Khatun, the wife of Hülegü. In Maragha, the Caliph's son married a Mongol girl and had two sons by her (Rashìd al-Dīn, 1954:714). The Caliph's other sons were killed two days after their father's death (Jūzjānī, 1970:1254(note 4).

${ }^{61}$ Kirakos Gandzakets'i, 1961:381.

62 Boyle, 1961:149.

${ }^{63}$ Marco Polo in Komroff, 2003:32; Boyle, 1961:146, 148.

${ }^{64}$ Grigor Aknerts' i, 1974:42; Sykes, 1930:96. 
of Waqaf, the Caliph was put to death along with his eldest son and five servants, but gives no specific description of the execution. ${ }^{65}$ According to Jūzjānī, the Caliph was rolled up in a carpet, trampled upon by horses and kicked to death. ${ }^{66}$ As this was the customary Mongol form of execution to prevent the shedding of the dignitaries' blood, this last account commonly followed by Western scholars. ${ }^{67}$

After accomplishing his task, Hülegü himself withdrew northwards, first to his ordu (headquarters) near Hamadān, and then into Azerbaijan. ${ }^{68}$ But before this, in order to maintain city life, the vizier and the șahib-diviann were both re-established in their offices on the same day as the Caliph's death. ${ }^{69}$ Hülegü also appointed other officers to collaborate with them and sent two noyans with 3,000 cavalrymen to rebuild Baghdad, to bury the dead, restore the mosque and tombs, and rebuild bazaars. ${ }^{70}$ Buqa-Temür was dispatched to complete the conquest of southern 'Irāq-i 'Arab and Khūzistan.

\section{The Mongol Penetration into Upper Mesopotamia}

The task apparently set by the court of the Great Khan was completed. The Ismā'îli and the 'Abbasid powers were subjugated. However, Hülegü continued his world-conquering programme. It is interesting to speculate about the reason why the Mongols were drawn into Syria and Palestine. There can be many reasons, such as that the war machine could not be stopped as the procurement of new lands occupied the army; alternatively, the concept of the liberation of the Holy Land attracted the Mongols. Another reason is that the Mongols saw a chance to fill the power-vacuum of this region, disputed as it was between the Christian and Muslim worlds, or even within the Muslim world between the Ayyubid princes and the new Mamluk (Mamlūk) state in Egypt. Modern scholarship is still working to elaborate the causes of the Mongols' penetration of Syria. ${ }^{71} \mathrm{We}$ might note that the Mongol Empire was still in it expansionist phase and naturally sought to follow one conquest with the next.

\footnotetext{
65 Rashīd al-Dīn, 1954:713.

66 Jūzjānī, 1970:1252-1253.

67 Boyle, 1961:150, 1968:349; Grousset, 1970:356.

68 Rashīd al-Dìn, 1954:715.

69 Ibid., 713.

70 Ibid., 714.

71 Amitai-Preiss, 2004:17.
} 
To my knowledge, there was no Great Quriltai's or Court mandate to control Syria and Egypt. It is not obvious who made the decision to conquer Syria. If we believe Het'um Patmich', it is only known, that the Armenian King Het'um twice expressed his interest to the Mongol Khan in freeing the Holy Land from the Muslims, once visiting Mönkge Khan in Qara-Qorum in 1253/1254, and the second time visiting Hülegü in Maragha in 1258. ${ }^{72}$

There is disagreement among the sources about what happened after the conquest of Baghdad and when Upper Mesopotamia was invaded. According to Rashīd al-Din, Hülegü set out from Azerbaijan to Syria on 12 September 1259. While moving towards Aleppo, he sent his son Yoshmūt to Mayyāfāriqīn and al-Ṣālih Ismāềl, the son of Badr al-Dīn Lu'lu', to Āmid (Amida). ${ }^{73}$ According to Kirakos Gandzakets'i and Vardan Arevelts'i, Hülegü despatched his son to besiege Mayyāfäriqīn and Amida soon after the fall of Baghdad, i.e., in the Spring of $1258 .{ }^{74}$ Jūzjāni is in agreement with them. ${ }^{75}$ Based on the narrations of Ibn-Shaddād (1217-1285), Patton states that Mayyāfāriqīn and Amida fell in November 1258, almost a year before Hülegü's raid on Syria. ${ }^{76}$

The Ayyubid ruler of Mayyāfāriqīn and Amida, al-Kāmil Muhammad, had broken his vow to Hülegü to supply troops for the siege of Baghdad. ${ }^{77}$ Nevertheless, Al-Kāmil tried to end the Mongol offensive through negotiation; however, the resistance of the Muslim army in Syria forced the Mongols to continue the siege. ${ }^{78}$ Both Kirakos Gandzakets' $i$ and Rashìd al-Dīn assert that the Mongol Ilkei Noyan, the ancestor of Jalayirids, initiated negotiations and summoned the

72 According to Het'um Patmich', before Hülegü's march on Syria, the Armenian king waited for Hülegü in Edessa to assert once more his Christian interest in the Mongol conquest of Palestine and the liberation of the Holy Land from the Sultan of Aleppo (Het'um Patmich', 1951:49-50).

${ }^{73}$ Rashìd al-Dīn, 1954:719.

${ }^{74}$ Kirakos Gandzakets'i, 1961:384; Vardan Arevelts'i, 1991:150.

${ }^{75}$ Jūzjānī, 1970:1269-1270.

76 Patton, 1991:63. Mayyāaāriqīn was a small city but a strong fortress (Jūzjānī, 1970:1268).

77 Al-Kāmil visited Mongolia to present his submission and was granted yarligh and paiza by Mönkge Khan in 650 H. (1253) (Rashīd al-Dīn, 1954:727; Humphreys, 1977:335). He came back to Iraq with Hülegü in 1257 (Jūzjānī, 1970:1266; Patton, 1991:62). In fact, al-Kāmil marched with his troops towards Baghdad, but to aid the Caliph. On his way, he received information about the fall of Baghdad and he turned back (Jūzjānī, 1970:1267-1268).

${ }^{78}$ Patton, 1991:63. 
people of the city of Mayyāfāriqin to surrender. ${ }^{79}$ The conditions were to pay taxes and provide troops to the Mongols. However, the Sultan refused and fortified the city. ${ }^{80}$ Yoshmūt and Ilkei Noyan left their troops in the city and went as far as the river Euphrates, taking quantities of booty before returning to the troops that were besieging Mayyāfāriqīn. Upon their request, Hülegü sent support, in the form of Mongol-Christian troops commanded by a certain Chaghatai (whom Rashīd al-Dīn calls ارقتو) and the Armenian Prince Pŕosh Khaghbakian. ${ }^{81}$ The Governor of Mosul, Badr al-Dīn Lu'lu', who was in conflict with al-Kāmil Muhammad, sent a supporting force to the Mongols commanded by his son, along with siege engineers to Mayyāfäriqinn. ${ }^{82}$ In the battle, catapults and arbalests were employed on both sides. ${ }^{83}$ In fact, Armenian sources relate different details of the siege of Mayyāfäriqin. Kirakos records that the city suffered so much from famine that one litr of human flesh was sold for seventy dahekans.$^{84}$ Sebastats $i$ states that one litr of human flesh cost a hundred dahekans. ${ }^{85}$ Grigor Aknerts'i explains that the city was besieged for three years because it was the city of martyrs full of holy relics and built by the holy Marut'a. The siege lasted until the citizens began to eat each other and the head of a donkey cost thirty drams (dirhems) ${ }^{86}$ Step'annos Episkopos states that the city was under siege for one year (1259) and fell due to Hülegü starving the citizens. ${ }^{87}$ Probably the city fell in April $1259^{88}$ but Amida held out until the beginning of $659 \mathrm{H}$. (1261). ${ }^{89}$ Another point stressed by Kirakos is that the sultan of the city was found by the Mongols faint from hunger. When he was brought to Hülegü, the latter gave orders to kill him along with his brother, as they were guilty of bloodshed and human casualties. ${ }^{90}$ Many people died on both sides. Vardan

\footnotetext{
79 Rashīd al-Dīn, 1954:725; Kirakos Gandzakets'i, 1961:384.

${ }^{80}$ Rashīd al-Dīn, 1954:725.

${ }^{81}$ Kirakos Gandzakets'i, 1961:385.

82 Patton, 1991:63.

${ }^{83}$ Jūzjānī, 1970:1272(note 5); Kirakos Gandzakets'i, 1961:385.

${ }^{84}$ Ibid., 385-386.

${ }^{85}$ Sebastats'i in Hakobyan, 1956:142.

${ }^{86}$ Grigor Aknerts'i, 1974:42.

87 Step'annos Episkopos, 1951:43.

${ }_{88}$ Vardan Arevelts‘i, 1991:150. According to Jūzjānī, Mayyāfāriqīn was besieged for more than three months (Jūzjānī, 1970:1270).

89 Patton, 1991:63.

${ }^{90}$ Kirakos Gandzakets'i, 1961:387. The same event is interpreted differently in the Persian source, where all the citizens except 70 people died from famine and
} 
Arevelts'i records that the Armenian Prince Sevada Khachents' $i$, the son of Prince Grigor, was killed in this battle. ${ }^{91}$ Nonetheless, churches and countless relics of the saints were saved in this city. The Armenian soldiers told the Mongols about the venerability of the relics and they even saw many visions of saints and bright lights over the walls of one particular church. ${ }^{92}$ Probably in the same church, the Armenian Prince Taq-i al-Din (Ountumpk ) from the Bagratuni family in Sasun, seized a Syrian priest and made him promise to return the right hand of the holy apostle Bartholomew. The holy relic was brought first to Taqi al-Dīn's monastery and then, on the demand of Lord Sadun, the grandson of Sadun Artsruni, it was deposited in the Monastery of Haghbat (in the district of Lorii)..$^{93}$ The Armenian source records that after the sack of these cities, the Mongols came to Sasun, and since Prince Sadun was a protégé of Hülegü, Sasun was given to him. ${ }^{94}$

\section{The Implementation of a Cilician Armenian Dream}

Hülegü stayed in Azerbaijan for over a year preparing for his third campaign against the Ayyubid states in Syria. ${ }^{95}$ He remained mostly in Maragha (Marāgheh), where, under his patronage, Nașir al-Dīn Țūsi and other scholars began to erect the famous astronomical observatory. ${ }^{96}$ As has been noted above, Hülegü had already asserted himself as the ruler of the new Mongol state in Rūm, Iraq, Iran, Afghanistan and the Caucasus. During the Summer of 1258, he received his vassals in Maragha: Badr al-Dīn Lu'lu of Mosul, atabeg Abū Bakr of Fārs, the Sultans of Rūm, 'Izz al-Dīn and Rukn al-Dīn, and the Caucasian lords. ${ }^{97}$

al-Kāmil Muhammad was tortured to death by being forced to eat his own flesh (Rashīd al-Dīn, 1954:727).

91 Vardan Arevelts'i, 1991:152.

${ }^{92}$ Kirakos Gandzakets'i, 1961:387. Jūzjānī records that there was a Christian church in the city of Mayyāfāriqīn called Markūmah which was full of sanctity (Jūzjānī, 1970:1268).

${ }_{93}$ Grigor Aknerts'i, 1974:42-43.

${ }^{4}$ Later, Sasun was sacked by the Mongols who broke their oath (Kirakos Gandzakets'i, 1961:386).

${ }^{95}$ Boyle, 1968:349.

96 Rashīd al-Dīn, 1954:718. Nașīr al-Dīn Ṭūsī produced for Hủlegü and his son Abaqa a treatise on government finance (Minorsky, 1964a:64-85).

${ }_{97}$ Boyle, 1968:349. 
The motive for these visits may have been related more to the extension of their agreement with the Mongols rather than to congratulate Hülegü on the occasion of his victory and proclamation as an Il-Khan. ${ }^{98}$ As the Armenian King Het'um wished, the Mongol Khan agreed to free the Holy Land from the Muslims. ${ }^{99}$

On the other hand, as Badr al-Dīn Lu'lu' of Mosul had greatly aided the Mongols in invading Iraq and overthrowing 'Abbasid's rule earlier on, ${ }^{100}$ there was a Muslim appeal against the Ayyubids as well. On the eve of the Mongol invasion, Egypt and Syria experienced a period of internal political conflict, civil disorder and conspiracies. ${ }^{101}$ Three major important Ayyubid figures: al-Nāșir Yūsuf b. al-'Azīz Muhammad, the Sultan of Aleppo and Damascus, al-Manșūr Muhammad b. al-Muzaffar Maḥmud, the ruler of Hamā, and al-Mughìth 'Umar b. al-'Ādil Abu Bakr, the ruler of Karak, had all shown their willingness to cooperate with the Mongols. Another Ayyubid, al-Ashraf Mūsā, the former Prince of Homș, had maintained a correspondence with the Mongols since $651 \mathrm{H}$. (1253-1254). ${ }^{102}$ In fact, al-Ashraf Mūsā encouraged Hülegü to invade Syria in order to be reinstated. ${ }^{103}$ Besides these, the other Ayyubid amirs, merchants and the chief chamberlain, as well as the Kurdish amirs, promoted a submissive policy towards Hülegü. ${ }^{104}$ There was also sectarian conflict between the Sunnis and the Shi' as, which might have encouraged Hülegü's determination to march on Syria. ${ }^{105}$ Therefore, in addition to the Cilician Armenian interest, there was a certain interest on the part of some Ayyubid leaders in bringing the Mongols to Syria.

As has been said above, Hülegü set out from Azerbaijan in September 1259, having sent ahead his general Ket-Buqa with the advance forces. According to Grigor Aknerts'i, Hülegü picked two

${ }^{98}$ It is not clear who bestowed the title Il-Khan on Hülegü. Amitai-Preiss suggests that Hülegü adopted the title of his own volition (Amitai-Preiss, 2004:14).

99 Ibid., 45-46.

100 Patton, 1991:3.

101 Amitai-Preiss, 2004:17.

${ }^{102}$ Humphreys, 1977:341-342; Amitai-Preiss, 2004:19-21.

103 Al-Ashraf Mūsā was received by Hủlegü at Aleppo and retained Homṣ and the title of the ruler over all Syria. Hủlegü also granted him an iqtă $\bar{a}^{\prime}$, revenues of land assignment (Amitai-Preiss, 2004:20, 31).

104 Ibid., 22.

${ }^{105}$ Besides the conflicts, palace intrigues reached a high level, which contributed to the decision of Hülegü (Rashìd al-Dīn, 1954:698-703). 
out of every ten men of the assembled army for the march on Syria. ${ }^{106}$ Hülegü demanded that the Georgian King David Ulu support his conquest of Syria and Egypt. Surprisingly, David refused. One might have expected that the Georgian king would have been more than interested in liberating the Holy Land. However, David was not only disinterested in this venture, but also bold enough to refuse Hülegü's order. In addition, he sought a revolt, which was suppressed by Arghun Aqa in Southern Georgia in $1260 .{ }^{107}$ David Ulu's refusal to participate in the Mongol campaign in Syria can be explained by his huge loss of men in the battle for Baghdad. In these circumstances, Hủlegü called for the Cilician Armenians and set out for Syria. He personally commanded the centre, placing commanders Baiju and Shiktür on the right flank and other amirs on the left. ${ }^{108}$ The army passed through Ala-Tagh, Akhlāt and the Hakkārī mountains into Diyārbakr or Amida, which was captured by the son of Badr al-Dīn Lu'lu'. ${ }^{109}$ Hülegü himself captured Edessa, Dunaysir, Nisībin/Nisibin and Harrān ${ }^{110}$ (see Map 5). After crossing the Euphrates, the Mongols surrounded Aleppo, where they were joined by the troops of the Cilician Armenian King Het'um and his son in-law, Bohemond VI, the Prince of Antioch (1252-1268) and the Count of Tripoli (12521275). ${ }^{111}$ Among those who arrived was the Armenian Catholicos Kostandin (Constantine) I (1221-1267) who came to bless Hülegü's march, as the Armenian chronicler attests, in order to 'free all the Christians, clerics and people from death. ${ }^{112}$ This account indicates the importance of this conquest for the Armenians.

The siege of Aleppo started. The inhabitants of Aleppo, trusting in the impregnability of their citadel and of the five secure gates (Jews' Gate, Anatolia Gate, Damascus Gate, Antioch Gate and Iraq Gate) refused to surrender and preferred to fight the Mongols. The

${ }^{106}$ Grigor Aknerts 'i, 1974:49. Estimates of the size of Hülegü’s army range from 15,000 to 120,000 (Smith, 1975:274-278; Allsen, 1987:203-207).

107 Kirakos Gandzakets ii, 1961:390.

108 Rashīd al-Dīn, 1954:719.

109 According to a Persian source, the army killed many Kurds in Akhlāt and in the mountains of Hakkārī (Rashīd al-Dīn, 1954:719).

110 Ibid., 719.

111 Boyle, 1968:350. The conquest of Aleppo signified the entrance of the Mongols into the principality of Antioch and the county of Tripoli. In return for his military support, Bohemond retained the districts in the Orontes valley which he restored to the principality of Antioch (Jackson, 2005a:117).

112 Vardan Arevelts'i, 1991:151. 
city was finally taken through the Iraq Gate and the siege of the town lasted less than a week. ${ }^{113}$ The following episode in the siege of Aleppo is documented by Smbat Sparapet:

In the year 1260, Khan Hulagu and his mighty host advanced like a Spring torrent, seizing the forts of the infidels wherever they passed, some peacefully, some by fighting. Thus he advanced as far as Aleppo, surrounded the city, and sent word to King Het'um to join him; and the latter immediately came to the Khan with his army, and the Khan received him joyfully. And the victorious Khan harassed Aleppo with numerous engines, and in seven days he opened a way for the invaders in spite of the great width of the ramparts and the depth of the ditch. Then they all raised such a loud cry that the earth shook and trembled at the sound; entering, they marched on the citadel. ${ }^{114}$

For many days and nights, they battled against the defenders in the citadel of Aleppo where catapults and arrows were used by both sides. ${ }^{115}$ As Bar Hebraeus relates, the greater number of the Christians were gathered in the church of the Greeks. The Armenian noble T'oros and the monk Kürāk liberated them and brought them to the Syriac church in Maragha. ${ }^{116}$ Ibn Shaddād and other Arab historians stress the reprehensible role of Het'um in the siege, who set fire to the Great Mosque of Aleppo. ${ }^{117}$ In Muslim historiography, this theme of the plunder of mosques by the Armenians continued until Il-Khan Ghazan's reign. ${ }^{118}$ Ibn Shaddād states that Hülegü, having learned what Het'um had done to the mosque, became angry and had a large number of Armenian troops massacred. ${ }^{119}$ To my knowledge, the contemporary Armenian sources say nothing about setting fire to the mosque, the massacre, the conversion of the mosque into a church, nor the execution of the Armenians by Hülegü. The reference to similar actions in Damascus, but this time attributed to Bohemond VI, is found in the Deeds of the Cypriots, saying:

The King of Armenia and the Prince of Antioch [Bohemond VI] joined the Tartar host and were at the taking of Damascus. When Damascus fell, the prince had a most lovely Church purified and censed ... This

${ }^{113}$ Rashīd al-Dīn, 1954:719. Aleppo was taken from 18 to 24 January and the citadel on 25 February 1260 (Boyle, 1968:350; Amitai-Preiss, 2004:26).

114 Smbat Sparapet Chronicle cited in Der Nersessian, 1973:370.

115 Rashīd al-Dīn, 1954:719.

116 Bar Hebraeus, 2003:436.

117 Boyle, 1968:350; Ibn Shaddād in Stewart, 2001:41.

118 See Chapter 7.

119 Jackson, 1980:495. 
was originally the church of the Greeks (that had been turned into a mosque) ... And in other Mohammedan mosques, where the Saracens worshipped, he had roncins and donkeys stabled, and he splashed wine on the walls and smeared them with pork, both salt and fresh. And where he commanded his men to commit one act of defilement, they did ten. ${ }^{120}$

When the city was conquered, many artisans were made prisoner. After the long siege of Hārim fortress near Aleppo, the defenders asked for mercy. ${ }^{121}$ But Hülegü was extremely angry with them and ordered them to be killed. Interestingly enough, only an Armenian goldsmith was spared. ${ }^{122}$ By this time, the notables of Hamā and Homṣ had come to Hülegü and submitted their cities to him. ${ }^{123}$ After Hārim fortress, the citadel of Aleppo was taken, and Hülegü installed a Mongol shahna in Aleppo. ${ }^{124}$

The people of Damascus were frightened by the attacks of the Mongol army. Hülegü ordered Ket-Buqa to go to Damascus and test them and Ket-Buqa arrived there on 14 February $1260 .{ }^{125}$ Since Aleppo was entirely under Hülegü's control, the dignitaries and grandees of Damascus came to the camp of Hülegü bearing all sorts of gifts and the keys to the city gates. ${ }^{126}$ Therefore, without having to lay siege, Ket-Buqa made a triumphal entry into Damascus on March 1, accompanied by the Armenian King Het'um and Bohemond VI. ${ }^{127}$ The inhabitants turned out to greet them and asked for amnesty. Ket-Buqa sent the nobles and dignitaries to Hülegü who showed mercy to them and granted their requests. ${ }^{128} \mathrm{~A}$ Mongol

${ }^{120}$ According to the Gestes des Chiprois, Bohemond converted one mosque into a Latin church and plundered many others (RHC/DA, 2, 171, 751; Crawford, 2003:34-35). Modern scholarship doubts this or any similar behaviour; see Jackson, 1980:486-487.

${ }^{121}$ On the siege of Hārim fortress, see Ibn Shaddād, 1984:42-43.

${ }_{122}$ Rashīd al-Dīn, 1954:720. It is a blacksmith in Bar Hebraeus, 2003:436.

${ }^{123}$ Kirakos Gandzakets'i, 1961:388.

124 Rashīd al-Dīn, 1954:720.

125 Amitai-Preiss, 2004:30.

126 Grigor Aknerts'i, 1974:49-50; Kirakos Gandzakets'i, 1961:388. The local notables decided to submit with the help of Zayn al-Ḥāfizị who had fostered a pro-Mongol policy for a long time (Amitai-Preiss, 2004:30).

127 Boase, 1978:26

${ }_{128}$ Among the nobles were al-Ashraf Mūsā whom Hülegü allowed to retain his old principality of Homș. Al-Sa id Hasan b. al-'Azīz 'Uthmān who had been released by Hủlegü from al-Nāșir Yūsuf s jail in al-Bīra on the Euphrates was reinstated as the ruler of al-Ṣubayba and Banias (Amitai-Preiss, 2004:31-32). 
shahna and three Persians were entrusted to govern Damascus. ${ }^{129}$ According to Kirakos Gandzakets 'i, after Damascus, Hülegü sent troops to the city of Mardin (Utpunhinuj). ${ }^{130}$ From Damascus, Ket-Buqa raided Hebron, Ascalon, Jerusalem and Nablus. ${ }^{131}$ Although scholars dispute the siege of Jerusalem by Hülegü, they agree that Hülegü was bound for the Holy Land. ${ }^{132}$ The reason why Hülegü was interested in the controlling of the Holy Land, which is stressed by Armenian historians, could be explained by the fact that the place was contested by the Christian and Muslim powers. By controlling the Holy Land, the Mongols could manipulate the sensitivities of both parties. However, Hülegü did not actually make any special arrangements for Jerusalem. By the time he had conquered Aleppo, al-Nāșir Yūsuf, the Sultan of Aleppo and Syria had fled to the fortress at Karak. ${ }^{133}$ Ket-Buqa wanted to lay siege to Karak but the Sultan of Aleppo asked for mercy and capitulated. Ket-Buqa sent al-Nāṣir Yūsuf to Hülegü in Tabriz who promised to give him the governorship of Syria after his defeat of Egypt. ${ }^{134}$

The main achievement of the Mongol-Cilician Armenian military alliance was the fall of Aleppo and Damascus. The alliance brought a certain immediate benefit to the Armenians. According to Het'um Patmich', after the capture of Syria and Palestine, King Het'um received territory in western Cilicia along with several fortresses taken from the Armenians by the Muslims. ${ }^{135}$ In fact, Het'um expanded his territories on the Cappadocian, Mesopotamian and Syrian borders where the trade routes passed. ${ }^{136}$ Hülegü gave Bohemond the port of Latakia in return for his reinstatement of the Greek patriarch of Antioch. ${ }^{137}$

\footnotetext{
${ }^{129}$ Rashīd al-Dīn, 1954:720. For shahna, see Chapter 4.

${ }^{130}$ Kirakos Gandzakets'i, 1961:388; Sebastats'i in Hakobyan, 1956:143.

131 Jackson, 2005a:116.

${ }^{132}$ Spuler, 1943:254. On the Mongol raid into Palestine, see Amitai, 1987(2):236255.

133 Al-Nāșir Yūsuf s ambivalent policy was due to his indecisive nature and opposite opinions of those around him (Amitai-Preiss, 2004:22).

${ }_{134}$ Rashīd al-Dīn, 1954:720.

${ }^{135}$ Het'um Patmich, 1951:50-51; Burger, 1988:xviii.

136 Stewart, 2001:46.

${ }^{137}$ Bohemond restored the districts in the Orontes valley (Kafr Bilmīs, Dayrkūsh and Kafr Dubbin) to the principality of Antioch which remained in his hands until it fell to Baybars in 1268 (Jackson, 2005a:117).
} 
In a short time in early 1260 , Syria and Palestine were conquered and brought under Hülegü's control. Now Hülegü confronted the last power of the Islamic states: Egypt, the dream of the Crusaders.

The achievement of Hülegü as a conqueror and an empire-builder is enormous. He was the carrier of the 'imperial ideology,' as AmitaiPreiss identifies this phenomenon. ${ }^{138} \mathrm{He}$ actively supervised battles on four different fronts: against the Ismāîliss; the 'Abbasid Caliphate; the Mamluks of Egypt and the Golden Horde (initially Ulus of Jochi). As has been said above, having destroyed both the 'Abbāsid Caliphate and its Ismāîlī opponents, Hülegü extended the Mongol conquest to the shores of the Mediterranean and left his successors in control of a territory corresponding to the greater part of what we now call the Middle East. As Boyle indicates, it is due to him and his successors that Iran came into direct contact with the West for the first time since antiquity. ${ }^{139}$

The involvement of Greater Armenia was mostly based on the obligations of their vassal status to serve in military actions. Among the Greater Armenian dynasties, Prosh Khaghbakian through his loyal service strengthened his position and his House, which later would be known as the Pŕoshians. ${ }^{140}$

The involvement of the Cilician Armenians, by contrast, was voluntary in the sense that it was consistent with their own interests and objectives and it had far-reaching political consequences. The Mongol victory in Mesopotamia allowed King Het'um I to expand his realm not only geographically to the Cappadocian, Mesopotamian and Syrian frontiers, but also economically, giving him the chance to control trade routes. ${ }^{141}$

Following his ancestral tradition of religious tolerance, Hülegü had no desire for a religious war. However, being reminded several times by the Armenian King Het'um, Hülegü saw clearly that there was a power-vacuum in this region that was disputed between the Christian and Muslim worlds. Moreover, he understood that, even within the Muslim world, control of Syria was contested between the

138 Amitai-Preiss, 2004:9.

139 Moreover, the dynasty founded by Hülegü may be said to have paved the way, however unwittingly, for the centralising nationalistic policies of the Șafavids (Boyle, 1968:355).

${ }^{140}$ Hovsep'ean, 1928:16-17, 36-45; Babayan, 1976:546-550.

${ }^{141}$ Stewart, 2001:46. 
Ayyubid princes and the new Mamluk state in Egypt. In order to reach his imperial goals, Hülegü drew on the resources and supports of his allies and subjects in the region. As has been said, among the first Mongols in Iran, the Christian interest was more influential; this is especially the case with the Il-Khanid hierarchy, in which the wife of Hülegü, Doquz Khatun, promoted the Christians. If the destruction of the Assassins brought much rejoicing to the orthodox Muslim world, the actual fall of Baghdad and the end of the 'Abbasid Caliph's line met with the opposite reaction. Lamentation over the fall of the glorious city of Baghdad is found in Muslim literature. The Arab writer adh-Dhahabi wrote a qașida, or ode, which belongs to the class of the marthiyya-qasidas, in which the final accord says that no-one hoped to remain alive after that veritable Day of Judgement; another was written by the famous Persian poet, Sa'di of Shiraz. ${ }^{142}$ Mongol incursions into Aleppo and the Ayyubid principalities of Syria and Palestine made the Mongols the most hated enemy of the Muslims. However, for the Christians, these raids represented some sort of divine judgement of the infidels. ${ }^{143}$

It is worth emphasising that a Muslim-Mongol alliance contributed to the success of Hülegü as much as a Christian one. The submissions and military services given by the Muslim rulers, namely Badr al-Lu'lu' of Mosul, Prince al-Ashraf Mūsā of Homṣ (at the beginning of his submission), al-Mughith 'Umar, the ruler of Karak, al-Sa id Hasan of Banias, and many others, had their own impact on the implementation of Mongol ambitions. ${ }^{144}$ On the other hand, despite the fractured political situation in Syria, Hülegü's conquest of Northern Syria made opposing Muslim leaders forget their past conflicts and unite against the Mongol threat. ${ }^{145}$

${ }^{142}$ Somogyi, 1933-1935:46-47; Browne, 1906:29-30.

143 Kirakos Gandzakets'i, 1961:383-384; Bar Hebraeus, 2003:423.

${ }_{144}$ Amitai-Preiss, 2004:32, 40.

145 Ibid., 2004:35. 